\title{
Defining Marriage: Classification, Interpretation, and Definitional Disputes
}

\author{
Fabrizio MACAgno
}

ArgLab, IFILNOVA. Faculdade de Ciências Sociais e Humanas

Universidade Nova de Lisboa

Avenida de Berna 26, 1069-061

Lisbon, Portugal

\begin{abstract}
The classification of a state of affairs under a legal category can be considered as a kind of condensed decision that can be made explicit, analyzed, and assessed using argumentation schemes. In this paper, the controversial conflict of opinions concerning the nature of "marriage" in Obergefell v. Hodges is analyzed pointing out the dialectical strategies used for addressing the interpretive doubts. The dispute about the same-sex couples' right to marry hides a much deeper disagreement not only about what marriage is, but more importantly about the dialectical rules for defining it.
\end{abstract}

Résumé: La classification d'une situation réelle dans une catégorie juridique peut être considérée comme une sorte de décision condensée qui peut être explicite, analysée et évaluée à l'aide des schèmes d'argumentation. Dans cet article, le conflit d'opinions controversées concernant la nature du «mariage» dans le procès Obergefell v. Hodges est analysé en soulignant les stratégies dialectiques utilisées pour faire face aux doutes reliés à l'interprétation. Le débat sur le droit des couples du même sexe de se marier cache un désaccord plus profond non seulement sur ce qu'est le mariage, mais surtout sur les règles dialectiques pour le définir.

Keywords: Interpretation, Pragmatics, Argumentation, Argumentation schemes, Meta-dialogues, Definition, Decision-making

\section{Introduction}

Definitions in law can play a crucial role for the decisionmaking process. The application of a rule to a case presupposes the classification of a state of affairs (or an entity) as falling under a legal category. This passage can be represented as a defeasible pattern of reasoning (Prakken 2005), whose defeasibility conditions consist in the possible alternative definitions (interpretations) of the legal term used in a statement of law, and the justification for its use in the given context (the characteristics of the state of affairs or entity) (Huhn 2002). Considering the specific deliberation-oriented function of this classificatory pattern in legal reasoning, legal classification can be considered as a condensed practical argument based on the choice of catego- 
rizing a state of affairs in a certain fashion, resulting in specific legal consequences (Westberg 2002, p. 163).

The process of classification hides a complex argumentative structure. In first place, it is an argument, namely a reason given in a specific context in support of an intended conclusion. Consequently, it is necessary to analyze not only its quasilogical dimension (its defeasibility) but also its pragmatic dimension (the speech acts used in advancing it). The fundamental premise of this argument, the definition or the definitional proposition, needs to comply with both pragmatic and quasi-logical conditions. Depending on whether a definition is proposed, justified, or taken for granted as shared, it needs to fulfill specific pragmatic requirements that have dialectical and rhetorical consequences (Macagno and Walton 2014; Macagno and Damele 2016). The analysis of the pragmatic dimension characterizing the use of a definition and the dialectical conditions governing it become of crucial importance for establishing the burden of providing arguments in support of a presumably unaccepted definition, and detecting the strategies for evading it.

The goal of this paper is to bring to light the logical, semantic, and dialectical structure of legal classifications, showing their essential relationship with the decision-making process. To this purpose, after introducing the theoretical argumentative background used to analyze classificatory arguments, the opinions set out in the decision of the famous case Obergefell $v$. Hodges 576 US , 2015) will be reconstructed and assessed. It will be shown how the discussion between the justices on the definition of marriage was focused not only on the meaning thereof, but more importantly on whether and how it is possible to establish one definition of a controversial concept. It will be pointed out how the roots of the deep disagreement can be found not only in the arguments supporting the advocated definiens, but more importantly in the implicit redefinitions that were taken for granted and thus presented as accepted. In this sense, this definitional conflict of opinions raises the question of how to discuss about a definition, and how to detect and counter the dialectical strategies for manipulating definitional discussions.

\section{Classification in law}

The structure of classificatory arguments in law is complex, as they support the premise needed for applying a rule to a case. For this reason, they become part of a decision, and involve the interpretive problems connected with the interpretation of legal texts. These different aspects can be represented using argumen- 
tation schemes, which can point out the essential premises and basic defeasibility conditions of legal classification.

\subsection{The argumentative structure of legal classification}

Classification plays a crucial role in applying rules, or more precisely legal prescriptions, to cases. The pragmatic nature of rules consists in guiding conduct, and for this reason rules can be considered as directives (Bach \& Harnish 1979, p. 47; Marmor 2013 , p. 47), namely texts (sentences uttered in a specific context and considering a specific background knowledge) expressing a general obligation or prohibition. For this reason, the passage from the generic "statement of law" to a specific legal rule - namely a specific prescription about how to behave in a specific circumstance - can be represented as a twofold process of reasoning, having the following pattern (Marmor 2013, p. 60):

(a) According to the law in $S$ (at time $t$, etc.) \{if $X$ [fact] then $Y$ [legal result]\}.

(b1) $E$ [something that happened in the world],

(b2) According to the law in $S, E$ counts as $X$, therefore, $X$.

(c) According to the law in $S,\{Y\}$.

This reasoning provides for two steps, one leading from a major directive premise (if $X$, then $Y$ ) to a legal prescription $(Y)$, the other from a fact $(E)$ to its classification pursuant to the relevant legal system $(S)$. Clearly, the two dimensions are essentially interconnected. The legal categorization of the perceived circumstances (the facts) is a choice that is constrained by the nature of the facts but is aimed at drawing a legal conclusion based on the available legal rules.

The two passages mentioned above are not only reasoning steps. Rather, when used to support a conclusion, they become arguments subject to questioning and affecting the burden of proof of the interlocutors. In order to describe their argumentative use, it is necessary to describe their dialectical structure, by setting out the material relation between premises and conclusion, and the defeasibility conditions (underminers, undercutters, or rebuttals) that can affect the probability of the conclusion (Weinstock, Goodenough \& Klein 2013; Walton 2016, p. 246).

The theoretical instrument that will be used to this purpose is constituted by argumentation schemes (Walton et al. 2008; Macagno et al. 2012; Macagno and Walton 2015). Argumenta- 
tion schemes are abstract patterns representing the combinations of premises and conclusion that characterize the most common natural arguments. They are dialectical in nature (they have a dimension of argumentation), inasmuch as they are combined with a set of critical questions that point out their defeasibility aspects. Critical questions are essential for assessing dialectically an argument. By answering such questions, or by failing to do so, the analyzer can determine how acceptable, or how presumptively acceptable, an argument is (Dascal and Wróblewski 1988). In this sense, the analysis of legal classifications using argumentation schemes brings to light the implicit premises and arguments underlying them, and more importantly provides a criterion for their dialectical evaluation. This analysis makes explicit the dialectical assessment procedure that should be followed ideally for evaluating an argument. Moreover, this argumentative tool allows understanding where and why the actual argument analysis was lacking, and what effects the incomplete argument assessment resulted in.

\subsection{The arguments of legal classification: argument from rules}

The first passage, leading from a general rule of law to a normative judgment, can be represented as an argument from rules having the following pattern (adapted from Walton, Reed, \& Macagno, 2008, p. 71):

\section{Argumentation scheme 1: Argument from rules}

\begin{tabular}{|c|l|}
\hline PREMISE 1: & $\begin{array}{l}\text { If carrying out types of actions including the state of affairs } \\
A \text { is the established rule for } V(x), \text { then (unless the case is an } \\
\text { exception), if } V(x) \text {, then } A \text { ought to be carried out. }\end{array}$ \\
\hline PREMISE 2: & $\begin{array}{l}\text { Carrying out types of actions including state of affairs } A \text { is } \\
\text { the established rule for } V(x) .\end{array}$ \\
\hline PREMISE 3: & $a$ has been classified as $V$. \\
\hline CONCLUSION: & Therefore, $A$ ought to be carried out relative to $a$. \\
\hline
\end{tabular}

This scheme has several dimensions of defeasibility. The first dimension consists in the passage from a legal text to a rule (premise 2). A rule is the result of a process of interpretation (Tarello 1980), namely the result of a pragmatic process of completion or specification of the incomplete sentence meanings (Soames 2008, pp. 296, 404; Dascal \& Wróblewski 1988, p. 213). In this sense, legal statements do not fully determine the 
meaning (objectively) expressed by the lawmaker, which is reconstructed through further pragmatic processes (Bezuidenhout 1997; Carston 2002; Capone 2009; Carston 2013). The second defeasibility condition concerns the possible conflicts between rules (premise 1). Rules can be subject to conflicts with other rules or values, or their application can be problematic in a specific case. In this case, the legal consequence may not follow from the classification and the rule. Finally, the rule may provide for exceptions, and the speaker needs to take into account whether the case is an exceptional one (premise 3). The critical questions are represented as follows:

$\mathrm{CQ}_{1}$ : Does the rule require carrying out types of actions that include $A$ as an instance?

$\mathrm{CQ}_{2}$ : Are there other established rules that might conflict with, or override this one?

$\mathrm{CQ}_{3}$ : Is this case an exceptional one, that is, could there be extenuating circumstances warranting an excuse for non-compliance?

The prima-facie passage from a text to its meaning, namely from the "incomplete" or "underspecified" sentence meaning to the speaker's meaning, corresponds to the process of automatic understanding of a text. If no doubts concerning it can be found or arise, the text is transparent or clear. If doubts can arise, they need to be solved through interpretive arguments, aimed at establishing the best interpretation (Dascal and Wróblewski 1988).

This pattern of argument provides the global structure of a type of practical reasoning (Rodriguez-Blanco 2013) grounded not on personal values but rather on legal rules, indications of what to do or what not to do in certain circumstances. The most critical premise is the classificatory one, establishing that an entity or fact falls under the legal classification " $V$." This argumentative step can be represented using a distinct scheme.

\subsection{The arguments of legal classification: argument from classification}

The crucial aspect of the aforementioned argumentation scheme is its relation with the classification of a state of affairs. A legal rule can be applied to a case only if a certain state of affair has been classified according to a relevant legal category. As Marmor put it (Marmor 2013, p. 60): 
[...] facts have to be incorporated into the law by some stipulation or other. To be sure, I am not suggesting that every legal inference has to incorporate the facts it relies upon to be prefixed by an explicit statement to that effect; that usually happens when the legal classification of the relevant facts is controversial. Otherwise, the stipulation is mostly implicit or presupposed. Notice, however, that even if the legal classification of the relevant facts is not contested or controversial, such classifications are always contestable. In principle, it is always possible to contest the incorporation of an alleged fact into the legal syllogism by claiming that in the eyes of the relevant law, $E$ [the action or event in the world] does not count as $X$ [the fact as required by the law].

The classification of a state of affairs as counting as having a legally relevant feature (to be a misdemeanor; to commit a theft, etc.) depends on a process of defeasible classification that is grounded on the circumstances and the meaning attributed in the context to the relevant legal predicate (the $X$ ) (Ross 1944). From the point of view of the legal decision-making process (application of a rule of law to a case), the classification step can be considered as a decision grounded on the relevant interpretation of the law, based on the circumstances of the state of affairs (see Rhonheimer \& Murphy, 2008, p. 84, for a discussion about the relationship between decision-making and the classification of a state of affairs). In this sense, the legal classification of a state of affairs is the conclusion of a pattern of reasoning. In this pattern, the classificatory premise consists in: 1) a rule of language taken for granted and drawn from the ordinary use of language; or 2) (in case of statutory definitions) a legal norm (Guastini 2011, pp. 56, 168), namely a second-order rule governing the interpretation of the legal statements and the application of the legal rules (Macagno and Damele 2016). In both cases, the classification is an intentional, deliberative act justified by a pattern of defeasible reasoning called "argument from classification," in which a new property (or a name) is attributed to an entity on the basis of other properties detected (Hastings 1963; Zarefsky 1998; Schiappa 2003; Zarefsky 2006; Walton and Macagno 2009; Walton and Macagno 2010). This argument can be represented as follows (Walton, Reed \& Macagno 2008, p. 319): 


\section{Argumentation scheme 2: Argument from classification}

\begin{tabular}{|c|l|}
\hline PREMISE 1: & $\begin{array}{l}\text { If some particular thing } a \text { can be classified as falling } \\
\text { under verbal category } C \text {, then } a \text { has property } V \text { (in virtue } \\
\text { of such a classification). }\end{array}$ \\
\hline PREMISE 2: & $a$ can be classified as falling under verbal category $C$. \\
\hline CONCLUSION: & $a$ has property $V$. \\
\hline
\end{tabular}

This scheme basically depends on the semantic principle connecting the property (or the category) $C$ with the classification $V$. This pattern is defeasible for two reasons. On the one hand, the classification of a state of affairs as $C$ in Premise 2 depends on a previous classificatory reasoning, which is in itself defeasible, as based on perception or observation (Ross 1944). On the other hand, also Premise 1 is defeasible, as it depends on: 1) a dialectical principle (the maxims of definition); and 2) a definition that is the outcome of an interpretive process.

This model of argument is grounded on a principle of inference establishing that "What the definition is predicated of, also the definiendum is predicated of" (Stump 2004, pp. 184, 221). The force of this locus depends on the force of the definition, and on whether the definition admits for possible exceptions or defaults. The argument can be based on various definitional criteria (Sorensen 1991; Walton and Macagno 2010; Macagno and Walton 2014) which include definition and other descriptions of meaning that only metaphorically can be considered as definitions, such as descriptions, metaphorical definitions, etymological definitions, etc. The strength of the maxim depends on the convertibility of the terms of the definition, which in turn depends on the type of definition chosen (Walton and Macagno 2009). The maxim of definition can apply to a case based on a "differentia," namely an interpretive premise that establishes that " $C$ is the definition (meaning) of $V$." This premise is the outcome of the interpretation of what the legal statement (which can be also a statutory definition) means in a specific context and co-text, considering various factors such as the ordinary meaning of the terms, the intended purpose of the law, etc. (Solan 2010:chap. 3; Solan \& Tiersma 2010, chap. 2; Macagno, Sartor \& Walton 2012; Walton, Macagno \& Sartor 2014; Dascal \& Wróblewski 1988).

The two dimensions of the argument from classification, corresponding to its defeasibility conditions, are represented by the 
following critical questions, which summarize the dialectical criteria for assessing the quality of a classificatory argument:

$\mathrm{CQ}_{1}$ : What evidence is there that $a$ definitely has property $C$, as opposed to evidence indicating room for doubt about whether it should be so classified?

$\mathrm{CQ}_{2}$ : Is the verbal classification in the classification premise based merely on an assumption about word usage that is subject to doubt?

The last critical question can be in turn specified further, pointing out the various defeasibility conditions concerning the classificatory premise:

$\mathrm{CQ}_{2.1}$ : According to the classificatory principle, is there room for exceptions (is it possible for an entity to be a $C$ and not a $V)$ ?

$\mathrm{CQ}_{2.2}$ : Is the classificatory principle (if $C$ then $V$ ) based on reasonable and sufficient grounds?

$\mathrm{CQ}_{2.3}$ : Are there alternative classificatory criteria for $C$ ?

$\mathrm{CQ}_{2.4}$ : In the given context, is there an alternative classificatory principle that is supported by stronger interpretative arguments?

These questions express the classificatory rule defaults (subquestion 2.1) and the interpretive defeasibility conditions (subquestions 2.2-2.4). These critical questions can be used to assess when and whether a definition (or meaning interpretation) is stronger or weaker than another.

\subsection{Arguments from classification and classificatory disputes}

As mentioned above, the use of a definition in law needs to be considered within the decision-making process of applying a rule to a case. The use of a definition amounts to a decision, which is based on reasons that are provided as a justification of the choice (Marmor 2013, pp. 59-60). This dimension of the argument from classification in law emerges when definitions are disputed, and arguments are provided in support of the recommendations for choosing a specific definition. The possibility of debating on the meaning of a legal term can be rooted in the vagueness or ambiguity thereof, the existence of different and conflicting definitions, or more critically, the controversial meaning of some of the elements of the definiens (Tarello 1980, pp. 155-156). Moreover, this issue is essentially related to the problem of establishing new classificatory criteria in case of 
open-textured concepts, or excluding or including specific entities from a classification based on reasons connected with policies or the purpose of the law (Sartor 2012).

The argumentative and dialectical nature of the arguments based on definitions can explain the importance of the rules governing the use of and the discussion on a definition. How to evaluate arguments in support or against a definition? How can a party evade the burden of defending a definition and what are the consequences thereof? These questions characterized one of the most critical and controversial definitional disputes in the recent years, namely Obergefell v. Hodges. In this case, the meanings of "marriage" and "liberty" were called into question and became the focus of a heated debate. This debate brought to light the stipulative nature of legal definitions and the role of definitional arguments. Moreover, it pointed out the issue of the burden of supporting a definition, the means to avoid it, and the meta-dialectical arguments and discussions concerning the rules and the obligations to define and redefine a term. In this sense, Obergefell is much more than a case about $a$ definition; it can be considered as a case on definition, and a dispute about how to define.

\section{The interpretive arguments in Obergefell v. Hodges}

In the fundamental judgment Obergefell v. Hodges (576 US__ 2015), the US Supreme Court held that the Fourteenth Amendment requires a State to license a marriage between two people of the same sex and to recognize a marriage between two people of the same sex when their marriage was lawfully licensed and performed out-of-State. This judgment, however, was highly controversial. Four of the nine justices of the Supreme Court disagreed with the majority opinion, and in the dissenting opinions some basic problems were raised that bring to light the complex nature of interpretive disputes. The analysis of the arguments provided on both sides can lead to identifying the deep roots of the disagreement, and the issues that need to be resolved in order to tackle them.

\subsection{Same-sex marriage: The arguments of the majority opinion}

The critical issue at stake in this case was whether same-sex marriage constitutes one of the fundamental rights and liberties protected by the Due Process Clause of the Fourteenth Amendment, which is breached by the States that deny it. The majority judges pointed out that in previous cases (Loving v. Virginia, 
Turner v. Safley, Zablocki v. Redhail) legal restrictions to marriage were invalidated because they breached a fundamental right. The reasoning by precedent here is aimed at broadening a legal category (marriage) to include same-sex unions, and attribute to them the same legal qualifications attributed in the past to cases of restricted marriage (Araszkiewicz 2011). This type of reasoning can be thought of as a kind of analogy (Ashley 1991; Friesen 1996; Macagno 2014; Macagno 2015) in which a concept is redefined to apply it to different cases. This analogical passage is supported by a further argument by precedent. In another previous case (Lawrence v. Texas), the court acknowledged that same-sex couples have the same right as opposite-sex couples to enjoy intimate association. For this reason, according to the majority opinion same-sex couples should be granted the same freedom of heterosexual couples, including marriage. In both analogical arguments, a category (marriage; freedom) is redefined and broadened to include same-sex marriage (Macagno and Damele 2016). The arguments advanced by the petitioners and upheld by the majority opinion can be summarized and represented as follows:

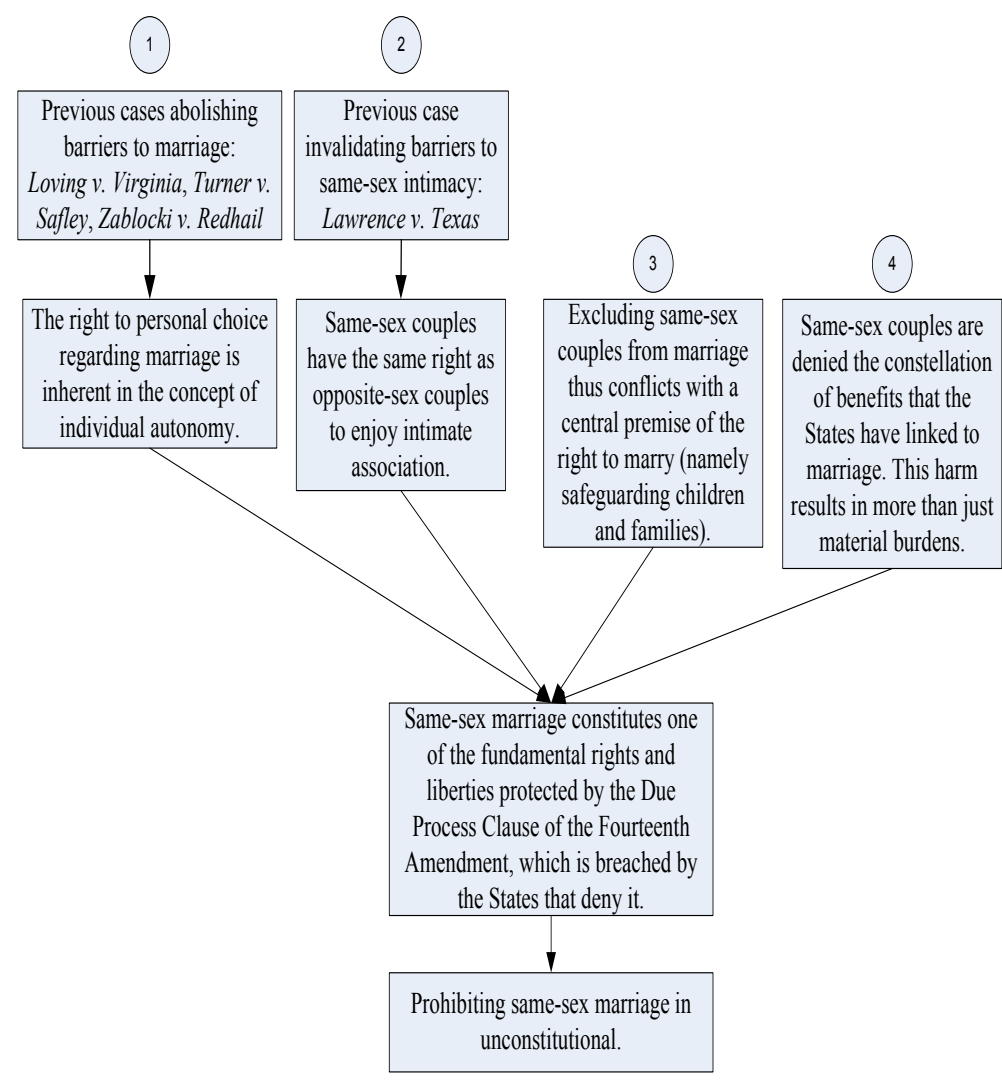

Figure 1: Summary of the majority opinion arguments 
The complex argument relies on two basic points:

1. Restricting the freedom to marry is a violation of a fundamental right, based on the previous cases in which specific restrictions to marriage (such as interracial marriage or marriage with people imprisoned) were considered as violation of such a right (1 and 3); and

2. Restrictions to liberties are violations of fundamental rights (2 and 4).

These arguments are relevant only because they appeal to the fundamental rights and liberties that are protected by the Due Process Clause of the Fourteenth Amendment. For this reason, the rebuttals of the dissenting opinion are focused on the constitutionality issues raised by the petitioners, namely the classification of the same sex couples' right to marry as a fundamental right and a fundamental liberty.

\subsection{Same-sex marriage: The arguments of the dissenting opinion}

The dissenting justices challenged the arguments provided in the majority opinion, attacking the premises on which they were based. The foundations of the two pillars of the majority opinion were called into question, as the definitions underlying them were countered. The underminers (Pollock 1974; Pollock 1987; Prakken 2010) can be summarized in two lines of argument (each directed against the two pillars of the concurring opinion) as follows:

1. The fundamental right to marry does not include the right to grant marriage benefits to same-sex couples. Such a right rests on the definition of marriage, which shall be decided by the people of the States.

2. The Fourteenth Amendment's requirement that "liberty" may not be deprived without "due process of law" does not apply, because no liberty has been denied.

The dissenting opinions focused on two crucial points on which the arguments are based: the definition of marriage, allowing for a same-sex union to be classified as marriage, and the definition of liberty in the Fourteenth Amendment, which would result in classifying the denial to grant the benefits of heterosexual married couples to same-sex couples as an infringement of a fundamental liberty. 
These attacks can be analyzed and represented as a series of underminers, undercutters, and rebuttals, which are represented in figure 2 below. The first underminer of the dissenting opinions is directed against the argument from analogy (previous cases) presented in the majority opinion. According to this analogical argument, the restrictions to personal choice concerning marriage are unconstitutional only if a union can be classified as marriage. The majority opinion left this redefinition implicit in the analogical argument (dotted lines), and did not explicitly challenge or rebutted the traditional definition. The dissenting judges attacked this implicit premise, aimed at broadening the definition of marriage. According to their reasoning, since same-sex unions cannot be considered as marriage according to its historical definition (marriage 1), and since a new, extensive definition (marriage 2 ) is controversial, the Court has no power to consider the denial of such alleged marriages as a breach to a constitutional right and freedom. On the contrary, the dissenting judges maintained that the decision of determining what counts as a marriage shall be left to the people, namely the States. This argument can be summarized and represented as follows:

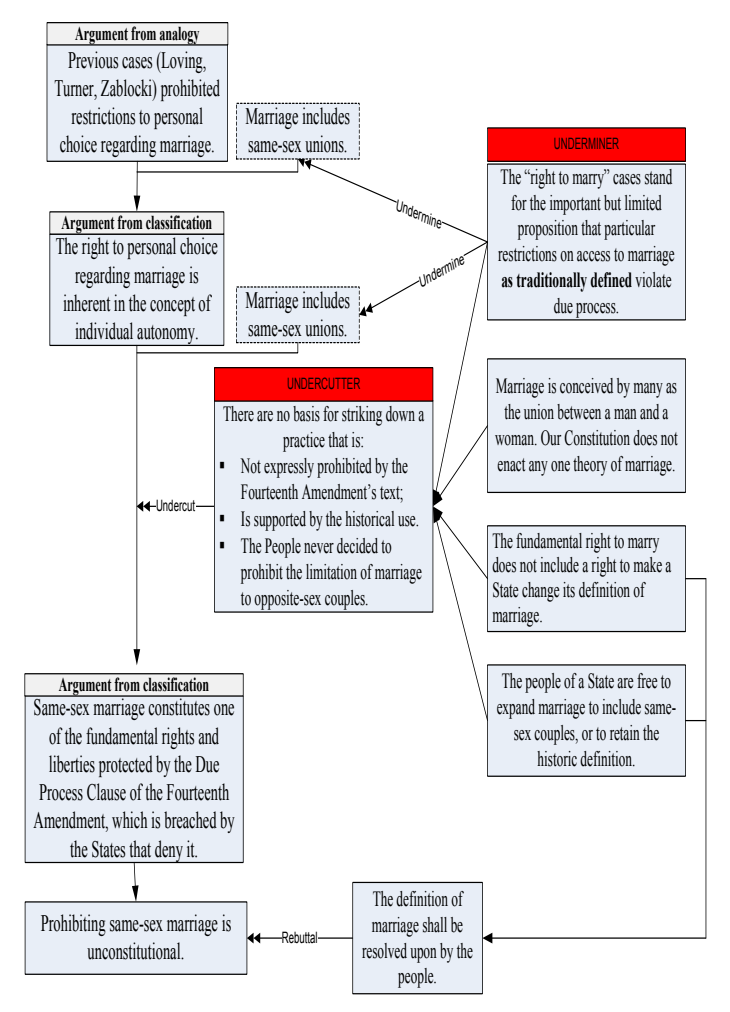

Figure 2: Undermining the redefinition of marriage 
In this figure, the focus of the underminers and the undercutters (Pollock 1970) is the foundation of the argument from classification. The majority judges used the arguments from precedent to support the view that the right to personal choice is a specific case of individual autonomy, which is a liberty protected by the $14^{\text {th }}$ amendment. By distinguishing between the traditional definition and the contested one, the argument from classification is deprived of its grounds, as the analogy between Loving and other cases and same-sex unions is rebutted. Moreover, by attacking the definition, both the classifications of "freedom to marry" as an individual autonomy and as a protected right are weakened.

If we consider the argument from classification mentioned above, we notice that the dissenting judges reduce the acceptability (or Baconian probability) of the argument from classification by using critical questions. They point out that the minor premise of the argument from classification (same sex marriage is marriage) cannot be accepted (CQ 1), attacking the underlying and implicit classificatory argument (based on the premise that marriage includes also same-sex marriage, which is also implicit in the analogical argument grounded on Loving and other previous cases). The distinction made underscores that three critical questions determining the acceptability of the implicit argument from classification (CQ 2.2-2.4) can be and are answered positively, resulting in lowering the acceptability of the conclusion. In this fashion, the judges provide arguments in favor of the defeasibility of the argument of the majority opinion. This does not mean that the argument is rebutted. It simply means that it is not proven, and requires further evidence or counter-arguments to be accepted.

The second argument of the dissenting opinion is an underminer directed against the implicit classification of "right to same-sex marriage" as a "liberty." The dissenting judges claim that denying same-sex couples the right to marry is not a breach of a fundamental "liberty," because no restrictions on individual freedom are in force in the States that do not grant such a right. Instead, such States refuse to grant benefits, namely entitlements that exist only because of the State itself. The counter-argument undermines the basis of the Petitioners' and the Majority's argument, namely that the right to same-sex marriage involves a constitutional and fundamental liberty. The problem raised is a definitional one: what counts as a liberty under the constitution? While the majority opinion does not tackle this issue, the dissenting opinion points out that philosophically and constitutionally speaking, "liberty" corresponds to negative liberty, namely liberty from something, not positive liberty (liberty to do some- 
thing). The argument can be summarized and represented as follows:

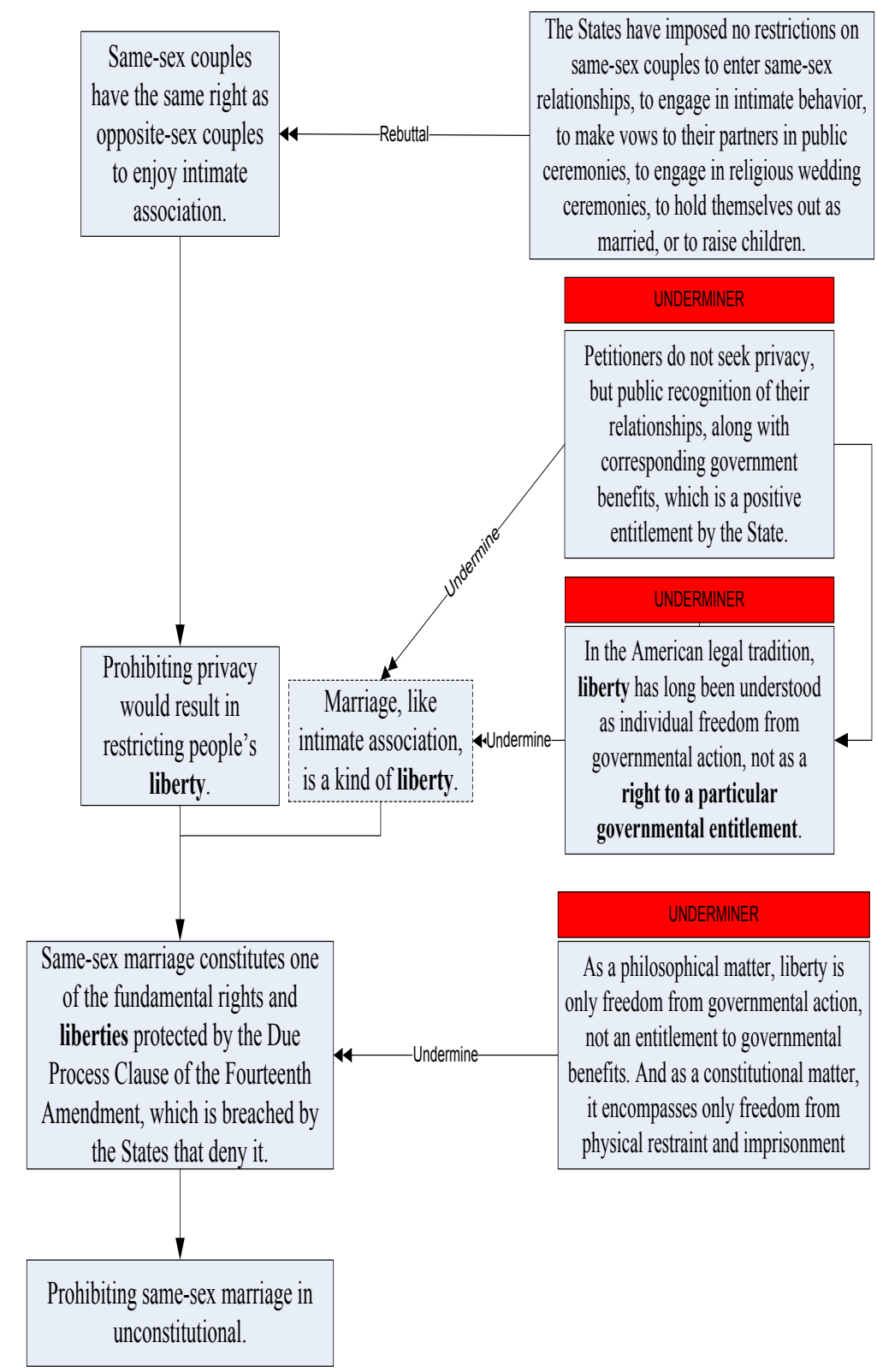

Figure 3: Undermining the redefinition of liberty

This argument is similar to the one represented in figure 2 above. The majority judges take for granted, in both their analogical arguments (from precedent case) that restrictions to same-sex marriage falls under the same categories of "restriction to marriage" (previous argument) and "restriction to liberty." Just like in the previous case, also here the compared cases are challenged. A breach to a liberty is claimed not to be the denial 
of an entitlement, as "liberty" cannot be defined or redefined as encompassing positive benefits. In both arguments the dissenting judges open a meta-dialogue based on a conflict of definitions.

\section{Conflicts of definitions and the power of defining}

As mentioned above, the conflict between the majority opinion and dissenting judges was based on two definitional issues, namely the definitions of "marriage" and "liberty." This case is particularly important because raises a concern that goes beyond the discussion about the relationship between definiens and definiendum of controversial terms. The problem of defining concepts that are "essentially contested" (Gallie 1955), or determining the specific contextual and co-textual meaning of terms that are vague or potentially vague (characterized by open-texture) (Hart 1961, p. 120; Bix 1991) needs to be distinguished from the possibility of debating thereon, and from the rules governing this discussion. In the first case, different methods or arguments can be used to support or challenge a definition or a classification (Macagno 2010; Macagno and Damele 2016), such as the analysis of the similarities and differences between the prototypical cases and the borderline ones (Bix 1991; Andersen 2000). In the second case, the problem is meta-dialogical, concerning the dialectical possibility and the conditions of the debate about the meaning of a contested, vague, or open-textured concept. In Obergefell $v$. Hodges, the problem pointed out by dissenting judges is this very meta-dialogical issue, concerning the rules of the dispute about definitions, which involve philosophical and political considerations.

\subsection{The definitions of marriage}

The first controversial definition concerns the meaning of "marriage." As the judges of the dissenting opinion acknowledged, the meaning of this concept is highly debated. The historical definition, presupposing the union of a man and a woman, is being challenged by a more extensive one that is becoming progressively accepted, which includes also same-sex unions. The judges of the majority opinion, instead of addressing this controversy and providing reasons in favor of one of the controversial definitions, grounded their arguments on a definition based on an ideal "nature" of marriage (at 13): 
The nature of marriage is that, through its enduring bond, two persons together can find other freedoms, such as expression, intimacy, and spirituality.

This definition, pointing out the "nature" or "true" dimension of a concept, advances a (highly controversial) description of meaning claiming that belongs to the "nature" of the concept described. This act of presenting a definition as accepted is a rhetorical and argumentative move. It is an argument, as it supports a legal decision, as it leads to a classificatory argument that is necessary for the justification of the decision (Schiappa 1993, p. 404; Schiappa 1996, p. 226). However, it is also a rhetorical move, as it posits as shared information that is controversial, and cannot be taken for granted (Macagno \& Walton 2014, chap. 5).

This rhetorical tactic hides two distinct powerful argumentative moves. On the one hand, this is a case of selective definition (Halldén 1960, chap. 7), namely a definition of a concept in which some of its commonly accepted characteristics are selected (Stevenson 1937; Stevenson 1938) and advanced as the most important ones, as the only ones that should be taken into account. On the other hand, this (re)definition is presented as shared by everybody, or as to be shared by everybody ("the nature" of...) (Macagno \& Walton 2014, pp. 142-145). By appealing to the "nature" of a concept, which corresponds to how a concept is commonly conceived (the shared meaning), the speaker shifts the burden of disproving the definition onto the possible opponents (the ones that do not accept what should belong to the common ground).

This move can be hardly justified in a context in which the "nature" of marriage is at stake. From a purely legal point of view, this alleged "nature" of marriage clearly conflicts with the historical definition that some judges of the Supreme Court and the legislative texts refer to. From a pragmatic point of view, the judges took for granted that an accepted definition of marriage exists, and that the proposed definition is accepted (from a legal point of view as well). Moreover, they reminded the interlocutors of a commitment of theirs, namely that this definition is the one that is considered as the shared one (the one that mirrors the "nature" of the concept defined). From a dialectical point of view, this move amounted to evading the burden of proving that the definition is actually the commonly accepted one, and shifted the burden of disproving it onto the opponents.

The effects of this rhetorical definition in this debate are extremely powerful. The concurring judges did not have to provide any argument in support of their redefinition (or at least controversial definition), while the dissenting judges had to 
challenge the definitional move by showing why it cannot be accepted (Macagno and Damele 2016). They pointed out that the precedent cases to which the majority opinion referred are based on the historical definition of marriage, which was never attacked or rebutted. Such cases, according to the dissenting judges, never redefined "marriage," but rather used the commonly shared (traditional) definition thereof:

Zablocki and Turner did not define marriage as "the union of a man and a woman, where neither party owes child support or is in prison." Nor did the interracial marriage ban at issue in Loving define marriage as "the union of a man and a woman of the same race." (Roberts at 10)

The point raised by the dissenting judges brings to light the crucial problem of meta-dialogues on the conditions of a discussion. A definition can be treated as belonging to the interlocutors' commitments (the implicit ones, at least) (Walton 1989, p. 178) when it is shared or non-controversial, or at least does not carry a burden of proof (Macagno \& Walton 2014, chap. 5). The interlocutor needs to be at least presumed to accept it or to have to accept it (based on laws or popular opinion). When it is not set out by laws or is not commonly shared, treating it as shared can be a potentially mischievous and controversial move. The dissenting judges rejected the dialogical move of the majority judges. They claimed that by taking for granted that a redefinition (in this case a definition that is not completely accepted from a legal and social point of view) is shared and shall be considered as such, the judges exercised a power that they do not have. They challenged the move as unacceptable from a dialectical point of view, as it breached a dialogical principle that results in the breach of a legal norm.

This dispute about the meaning of marriage shows how complex the dispute actually is. The problem is not simply how marriage is conceived, but what is under discussion. While the majority of the judges argue about the constitutionality of a kind of discrimination, the dissenting judges are concerned about whether it is possible to talk about discrimination, and who has the authority of classifying a union as a marriage. In this case, there is not even a common ground on which a conclusion can be reached, as the subject matter under discussion is not agreed upon.

\subsection{Defining liberty}

The second definition that is at the basis of the conflict between the judges is the concept of "liberty." The majority judges point 
out that the Due Process Clause of the Fourteenth Amendment claims that no State shall "deprive any person of life, liberty, or property, without due process of law." According to the Court, "these liberties extend to certain personal choices central to individual dignity and autonomy, including intimate choices that define personal identity and beliefs" (at 10). Since marriage is matter of personal choice, and it is one of the most intimate that a person can make (at 12), the liberty of choosing whom to marry shall fall within the liberties central to individual autonomy protected by the Constitution.

This argument is grounded again on a presupposed controversial redefinition. By redefining "marriage" as an enduring bond aimed at other freedoms, the court took also for granted that same-sex marriage is a constitutional right. Consequently, a constraint to the liberty of union becomes a breach to a constitutional liberty. Also in this case, the implicit redefinition needs to be argued against by the dissenting judges, who instead took for granted the currently acknowledged rights and entitlements. They claimed that the petitioners asked for the abolition of constraints to the "liberty" of choosing whom to marry, which is, however, an entitlement:

Even assuming that the "liberty" in those Clauses encompasses something more than freedom from physical restraint, it would not include the types of rights claimed by the majority. In the American legal tradition, liberty has long been understood as individual freedom from governmental action, not as a right to a particular governmental entitlement. [...] Instead, the States have refused to grant them governmental entitlements. Petitioners claim that as a matter of "liberty," they are entitled to access privileges and benefits that exist solely because of the government. (Thomas at 7)

As a philosophical matter, liberty is only freedom from governmental action, not an entitlement to governmental benefits. And as a constitutional matter, it is likely even narrower than that, encompassing only freedom from physical restraint and imprisonment. (Thomas at 13)

This liberty, according to the dissenting judges, amounts to granting a new right (namely marriage entitlements to couples that allegedly do not fall within the legal definition of marriage). By rejecting the redefinition of marriage, the judges had to reject another implicit redefinition, namely the use of the concept of "liberty" to include the entitlement to a new right. According to justice Thomas, since a union between same-sex individuals has not been defined unanimously and legally as a marriage, the government is not depriving individuals of a right or a liberty, 
but rather it is not granting them an entitlement that was not existing before. His reasoning can be summarized as follows:

1. Same-sex marriages are not marriages.

2. Same-sex marriages cannot involve the liberty of choosing whom to marry to (as they are not marriages).

3. The liberty of choosing whom to marry to for same-sex couples derives from a governmental entitlement, who grants a new right.

4. Therefore, the liberty of choosing whom to marry to for same-sex couples is not a liberty from a restraint, but an entitlement.

This counter-argument, undermining the classification of the Court, questions one essential presupposition, that same-sex marriages are an instance of marriage. By rejecting this presupposition, the whole argument collapses, and can be reconstructed only by assuming that the Court intended to define "liberty" as also including an entitlement to a new right.

\section{Conclusion}

In legal decision-making, the classification of a state of affairs under a legal category can be considered as a decision, whose justification can be represented as a defeasible pattern of argument. Argumentation schemes mirror the dialectical and defeasible nature of natural arguments, pointing out their potential defaults that the interlocutor (the opponent) can bring to light. In this sense, the assessment of an argument is a dialectical process in which the parties ask and answer critical questions, thus reducing, establishing, or increasing the acceptability of the argument.

This theoretical background can be applied to the analysis of legal cases. In this paper, the controversial conflict of opinions between the concurring and dissenting judges in Obergefell v. Hodges was analyzed, in order to bring to light the source of the disagreement. The conflict lies in the classification of samesex marriage, and in the argument that the judges of the majority opinion brought forward. They did not challenge or start a discussion about the meaning of marriage. Instead, they set out a definition that is at present extremely controversial and under discussion in the various states of the United States, and posited it as mirroring the "nature" of marriage. In this fashion, they implicitly excluded the alternative (traditional) definition, and treated the new one as the one that is and should be shared. 
The theoretical relevance of this dialectical and rhetorical move is illustrated in the counter arguments raised by the dissenting judges. In order to challenge the arguments supporting the decision of the Supreme Court, the dissenting justices had to rebut the proposed and granted definition, defending the traditional definition of marriage and the fact that it is legally and commonly accepted (or is at least matter of discussion). They argued against the fact that the new definition is commonly accepted, attacking the argument from classification used by the majority judges providing arguments supporting its defeasibility conditions set out in the critical questions. This discussion would have been a simple dialectical discussion should the definition be not taken for granted. The concurring judges, however, evaded the burden of proving that it is the commonly shared and legally accepted definition. This resulted in a meta-dialogue on the conditions and rules of the dialogue itself.

The crucial meta-argument advanced by justices Thomas and Scalia is that the Supreme Court has no power of defining a word such as marriage. By challenging the rules of the discussion, the showed how the disagreement about the same-sex couples' right to marry hides a much deeper disagreement about who has the power of defining a term. Schiappa maintained that all definitions are a matter of power, but this legal case shows how the problem is much more complex. The political and legal issue derives from the dialectical problem of establishing what happens when an argument justifying a decision cannot be accepted, and what this amounts to. By taking for granted a definition that is not shared, the concurring judges allegedly took on the power of defining and imposing a definition. This pragmatic and dialogical breach exceeds the dimension of the dialectical discussion. It becomes a meta-discussion about the roles and the powers of the parties to it.

Acknowledgements: I would like to thank the Fundação para a Ciência e a Tecnologia for the research grants no. IF/00945/2013 and PTDC/IVC-HFC/1817/2014.

\section{References}

Andersen, Hanne. 2000. Kuhn's account of family resemblance: a solution to the problem of wide-open texture. Erkenntnis 52: $313-337$.

Araszkiewicz, Michał. 2011. Analogy, similarity and factors. In Proceedings of the 13th international conference on artificial intelligence and law, 101-105. New York: ACM. 
Ashley, Kevin. 1991. Reasoning with cases and hypotheticals in HYPO. International Journal of Man-Machine Studies 34: 753-796. doi:10.1016/0020-7373(91)90011-U.

Bach, Kent, and Robert Harnish. 1979. Linguistic communication and speech acts. Cambridge, Mass.: MIT Press.

Bezuidenhout, Anne. 1997. Pragmatics, semantic undetermination and the referential/attributive distinction. Mind 106: 375-409. doi:10.1093/mind/106.423.375.

Bix, Brian. 1991. HLA Hart and the "open texture" of language. Law and Philosophy 10: 51-72.

Capone, Alessandro. 2009. Are explicatures cancellable? Toward a theory of the speaker's intentionality. Intercultural Pragmatics 6: 55-83. doi:10.1515/IPRG.2009.003.

Carston, Robyn. 2002. Thoughts and utterances: the pragmatics of explicit communication. Oxford: Blackwell Publishing Ltd.

Carston, Robyn. 2013. Legal texts and canons of construction: a view from current pragmatic theory. In Law and language: current legal issues, ed. Michael Freeman and Fiona Smith, 15:8-33. Oxford: Oxford University Press.

Dascal, Marcelo, and Jerzy Wróblewski. 1988. Transparency and doubt: understanding and interpretation in pragmatics and in law. Law and Philosophy 7: 203-224.

Friesen, Jeffrey. 1996. When common law courts interpret civil codes. Wisconsin International Law Journal 15: 1-27.

Gallie, Walter Bryce. 1955. Essentially contested concepts. Proceedings of the Aristotelian society 56: 167-198.

Guastini, Riccardo. 2011. Interpretare e argomentare. Milano: Giuffrè.

Halldén, Sören. 1960. True love, true humour and true religion: a semantic study. Lund: Gleerlup.

Hart, Herbert Lionel Adolphus. 1961. The concept of law. Oxford: Oxford University Press.

Hastings, Arthur. 1963. A reformulation of the modes of reasoning in argumentation. Evanston, Illinois: Ph.D. Dissertation, Northwestern University.

Huhn, Wilson. 2002. The use and limits of syllogistic reasoning in briefing case. Santa Clara Law Review 42: 813-862.

Macagno, Fabrizio. 2010. Definitions in law. Bulletin Suisse de Linguistique Appliquée 2: 199-217. doi:10.1007/978-94011-3346-3 12.

Macagno, Fabrizio. 2014. Analogy and redefinition. In Systematic approaches to agument by analogy, ed. Henrique Ribeiro, 73-89. Cham: Springer International Publishing. 
Macagno, Fabrizio. 2015. Arguments of interpretation and argumentation schemes. In Studies on argumentation and legal philosophy. Further steps towards a pluralistic approach, ed. Maurizio Manzin, Federico Puppo, and Serena Tomasi, 51-80. Trento: Università degli studi di Trento.

Macagno, Fabrizio, and Giovanni Damele. 2016. The hidden acts of definition in law - Statutory definitions and burden of persuasion. In Logic in the theory and practice of lawmaking, ed. Michal Araszkiewicz and Krzysztof Pleszka, 225-251. Cham: Springer.

Macagno, Fabrizio, Giovanni Sartor, and Douglas Walton. 2012. Argumentation schemes for statutory interpretation. In Argumentation 2012. International conference on alternative methods of argumentation in law, ed. Jaromír Šavelka, Michal Araszkiewicz, Matěj Myška, Terezie Smejkalová, and Martin Škop, 63-75. Brno: Masarykova univerzita.

Macagno, Fabrizio, and Douglas Walton. 2014. Emotive language in argumentation. New York: Cambridge University Press.

Macagno, Fabrizio, and Douglas Walton. 2015. Classifying the patterns of natural arguments. Philosophy \& Rhetoric 48: 26-53. doi:10.1353/par.2015.0005.

Marmor, Andrei. 2013. Truth in law. In Law and language, ed. Michael Freeman and Fiona Smith, 45-61. Oxford: Oxford University Press.

Pollock, John. 1970. The structure of epistemic justification. American Philosophical Quarterly 4: 62-78.

Pollock, John. 1974. Knowledge and justification. Princeton: Princeton University Press.

Pollock, John. 1987. Defeasible reasoning. Cognitive Science 11: 481-518. doi:10.1016/j.neuropsychologia.2008.11.011.

Prakken, Henry. 2005. AI \& Law, logic and argument schemes. Argumentation 19: 303-320. doi:10.1007/s10503-005-44187.

Prakken, Henry. 2010. An abstract framework for argumentation with structured arguments. Argument \& Computation 1: $93-$ 124. doi:10.1080/19462160903564592.

Rhonheimer, Martin, and William Murphy. 2008. The perspective of the acting person: essays in the renewal of Thomistic moral philosophy. Washington: CUA Press.

Rodriguez-Blanco, Veronica. 2013. Claims of legal authorities and "expressions of intention": the limits of philosophy of language. In Law and language: current legal issues, ed. Michael Freeman and Fiona Smith, 15:79. Oxford: Oxford University Press. 
Ross, A. 1944. Imperatives and logic. Philosophy of Science 11: $30-46$.

Sartor, Giovanni. 2012. Defeasibility in legal reasoning. In The logic of legal requirements. Essays on defeasibility, ed. Jordi Ferrer Beltrán and Giovanni Battista Ratti, 108-136. Oxford: Oxford University Press.

Schiappa, Edward. 1993. Arguing about definitions. Argumentation 7: 403-417. doi:10.1007/BF00711058.

Schiappa, Edward. 1996. Towards a pragmatic approach to definition: "wetlands" and the politics of meaning. In Environmental pragmatism, ed. Eric Katz and andrew Light, 209-230. New York: Routledge.

Schiappa, Edward. 2003. Defining reality. Definitions and the politics of meaning. Carbondale and Edwardsville: Southern Illinois University Press.

Soames, Scott. 2008. Philosophical essays, volume 1. Natural language: what it means and how we use it. Princeton: Princeton University Press.

Solan, Lawrence. 2010. The Language of statutes: laws and their interpretation. Chicago: University of Chicago Press.

Solan, Lawrence, and Peter Tiersma. 2010. Speaking of crime: the language of criminal justice. Chicago: University of Chicago Press.

Sorensen, Roy. 1991. Vagueness and the desiderata for definition. In Definitions and definability: philosophical perspectives, ed. James Fetzer, David Shatz, and George Schlesinger, 71-109. Dordrecht: Springer.

Stevenson, Charles. 1937. The emotive meaning of ethical terms. Mind 46: 14-31.

Stevenson, Charles. 1938. Persuasive definitions. Mind 47: $331-350$.

Stump, Eleonore. 2004. Boethius's "De topicis differentiis." Ithaca and London: Cornell University Press.

Tarello, Giovanni. 1980. L'interpretazione della legge. Milano: Giuffrè.

Walton, Douglas. 1989. Dialogue theory for critical thinking. Argumentation 3: 169-184. doi:10.1007/BF00128147.

Walton, Douglas. 2016. Argument evaluation and evidence. Cham: Springer.

Walton, Douglas, and Fabrizio Macagno. 2009. Reasoning from classifications and definitions. Argumentation 23: 81-107. doi:10.1007/s10503-008-9110-2.

Walton, Douglas, and Fabrizio Macagno. 2010. Defeasible classifications and inferences from definitions. Informal Logic 30: 34-61. 
Walton, Douglas, Fabrizio Macagno, and Giovanni Sartor. 2014. Interpretative argumentation schemes. In JURIX 2014: the twenty-seventh annual conference, ed. Rinke Hoekstra, 2122. New York: IOS Press.

Walton, Douglas, Christopher Reed, and Fabrizio Macagno. 2008. Argumentation schemes. New York: Cambridge University Press.

Weinstock, Charles, John Goodenough, and Ari Klein. 2013. Measuring assurance case confidence using Baconian probabilities. In Proceedings of the 1 st international workshop on assurance cases for software-intensive systems, 7-11. San Francisco: IEEE Press.

Westberg, Daniel. 2002. Right practical reason: Aristotle, action, and prudence in Aquinas. Oxford: Clarendon Press.

Zarefsky, David. 1998. Definitions. In Argument in a time of change: Definitions, frameworks, and critiques, ed. James Klumpp, 1-11. Annandale, VA: National Communication Association.

Zarefsky, David. 2006. Strategic maneuvering through persuasive definitions: Implications for dialectic and rhetoric. Argumentation 20. Springer: 399—416. 